\title{
Entangled Narrative Biographies of the Colossal Sculptures of Bāmiyān: Heroes of the Mythic History of the Conversion to Islam
}

\author{
Deborah Klimburg-Salter
}

\begin{abstract}
The entangled biographies of the Bamiyan Colossi, introduced in this article, point to a strategy for revitalization of the monumental niches that would support sustainable economic development and peace building. Today the empty niches invite visitors to complete the space according to their own imagination. A mixed media strategy of interpretive programs could narrate the evolution of the Colossi's identity through their changing biographies. Created in the late sixthearly seventh centuries, the Colossi were worshipped as Buddha images. Gradually adherents of the new religion, Islam, increased. By the tenth century the Buddhist community migrated from Bamiyan, taking with them the precious copper-alloy face masks and arm coverings. The resultant strange, awe-inspiring appearance of the Colossi encouraged the changing interpretations from idol (but) to "wonder" ( 'Ajā'ib). By the eighteenth century the Colossi were integrated into the mythic history of the Islamization of Bamiyan. These legends were recorded in the early twentieth century: "although the whole world knows that the two colossi represent Buddhas, the inhabitants of Bamiyan are not of our opinion" (Hackin R, Kohzad AA, Légendes et coutumes afghanes. Presses universitaires de France, Paris, 1953). Rather, the miraculous deeds of Hazrat-i Ali, the 4th Caliph, provides the framing device that unites the extraordinary natural and sculpted formations of Bamiyan including the colossal images Salsal and Shamama.
\end{abstract}

Keywords Afghanistan - Art history · Heritage preservation · Conversion to Islam - Collossal Bamiyan Buddhas · Salsal and Shamama

Published jointly by the United Nations Educational, Scientific and Cultural Organization (UNESCO), 7, place de Fontenoy, 75007 Paris, France, the UNESCO Office in Kabul, ICON Compound, Supreme Road, Off Jalalabad Road, PD 9, Kabul, Afghanistan, and Springer Nature Switzerland AG, Gewerbestrasse 1, 6330 Cham, Switzerland.

D. Klimburg-Salter $(\bowtie)$

Institute of Art History, University of Vienna, Vienna, Austria

Department of South Asian Studies, Harvard University, Cambridge, MA, USA

e-mail: klimburgsalter@fas.harvard.edu 


\section{Introduction}

After 14 Expert Working Group Meetings for the Safeguarding of the Cultural Landscape and Archaeological remains of the Bāmiyān Valley World Heritage Property, Afghanistan and the painstaking definition of goals and procedures, one of the most difficult problems remains unsolved: what is the most effective way to revitalize the great rock façade that contained hundreds of rock-cut decorated shrines and, most visibly, the colossal niches - each of which once contained a colossal image. Many of the issues that converge on the process and solutions for this problem are discussed in the contributions to this book. This article is the story of the entangled biographies of the colossal sculptures.

The purpose of the present paper is to contribute to this dialogue a neglected narrative interpretation of the colossal images and the sacred landscape in which they are embedded (Fig. 1). An examination of the literary, art historical, and archaeological sources for the history of the Colossal Buddhas demonstrates that their appearance and meaning changed dramatically after they ceased to be worshipped and the Buddhist communities had migrated from the Bamiyan Valley. Once they were no longer regarded as Buddha images the Colossi were reinterpreted, and as we shall see, took on new identities. Following several transformations, the Colossi were integrated into the mythic history of the Islamization of Bamiyan. Although the first literary reference to the "highly local" biography of the Colossi (Inaba 2019: 93) is found in a western literary source as early as the end of the eighteenth

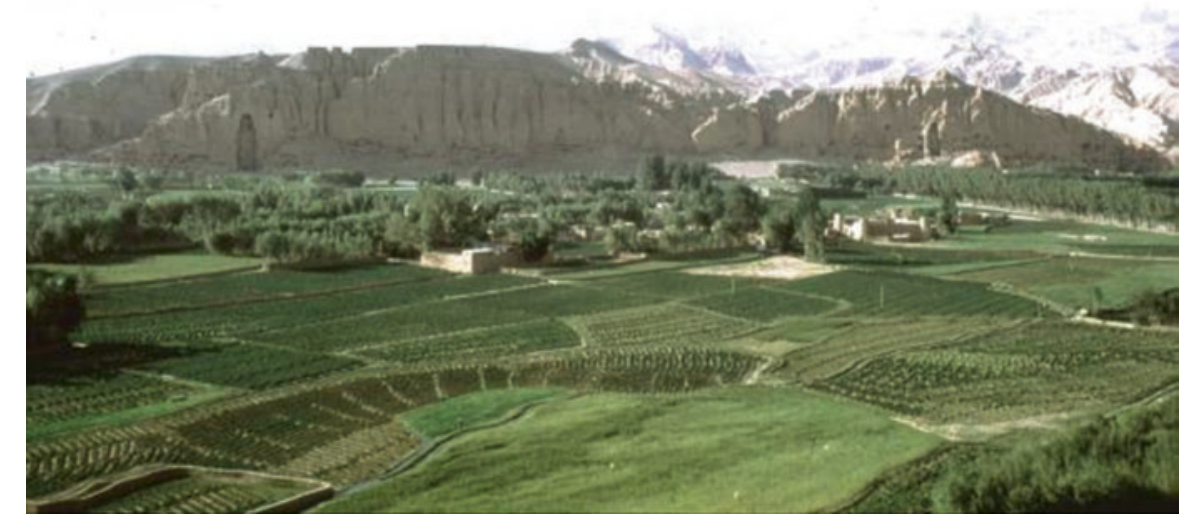

Fig. 1 Great cliff at Bāmiyān 
century, this interpretation of the Colossi never found acceptance outside the Afghan community. In the final section of this article I propose that the entangled biographies point to a strategy for the treatment of the monumental niches that would support both sustainable economic development and the peace building process.

The guidelines and goals of the Cultural Heritage Preservation Process discussed here are succinctly expressed in the following UNESCO documents: Draft Concept Note (2016) and the Recommendations of the 14th Expert Working Group Meetings (2017a, b).

The goals and rationale for the meeting have been eloquently summarized in the Draft Concept Note. Particularly relevant for this paper is the commitment to the important role that "... culture can play in [the] peace-building and development process specifically in conflict or post-conflict regions" (p. 5) It has been recognized that an important aspect of the peace-building process in post-conflict environments is the revitalization of identity, thus the importance of the section on "Community Empowerment and Development in the Bamiyan Valley" (Recommendations: Section 1, p.2).

\section{Guidelines and Goals for the Heritage Process}

Particularly relevant here is that portion of the Recommendations which proposes that the future treatment of the colossal niches should be considered in relationship to the broad spectrum of the cultural history of the Bamiyan Valley. Towards this end UNESCO working groups have consulted both professionals in a wide range of disciplines as well as civil society representatives, and a consensus was reached which, greatly simplified, can be summarized:

The guidelines for the protection of the material and immaterial heritage of the Cultural Landscape and Archaeological Remains of the Bāmiyān Valley World Heritage Property.

Changes, additions, or activities within the protected area should be consistent with:

1. the cultural history of the valley,

2. international conservation standards and guidelines

\section{The Goal of the Preservation Process}

1. to support sustainable economic development including tourism.

2. to contribute to the peace-building process

A successful solution for the archaeological zone would respect the long evolving history of the World Heritage Site and implicitly represent the interests of all stakeholders. Bamiyan is important to international and national 
stakeholders - beginning with the local stakeholders who are the people of the Bamiyan Valley and Bamiyan province. But first - it is necessary to understand how the modern narrative biography of the Colossi resulted both from their changing appearance and historical contexts.

The most contentious aspect of the question of the future treatment of the great façade focuses on the question - should at least one of the Buddhas be reconstructed?

Over the last 14 years the possible answers to this question have grown more sophisticated and differentiated. Despite subtle variations there are still essentially two major positions. One is that there should be a physical presence that would memorialize the colossal Buddhas.

The opposing position believes that the Buddhas are best memorialized without a physical presence. Thus, the empty niches are considered the most powerful statement memorializing the Colossi and their violent destruction. As shall be discussed in the concluding section, the empty niches have a multi -layered symbolic value. The empty niches offer greater interpretive flexibility and thus the greater potential to contribute to the peace building process. The proponents of this position also base their argument on the difficulty in reconstructing even one of the Buddhas according to international conservation guidelines.

An additional point of dispute is the relative economic advantages for the local residents related to each solution. This paper supports the position that the absence of a physical presence in the great niches has a greater interpretive flexibility and therefore the greater potential to contribute to the peace building process.

The following outline of the history and reception of the Colossi includes the evidence for the appearance and methods of construction of the Great Buddhas as a basis for evaluating which of the solutions are most likely to accord with both the guidelines and goals of heritage preservation as listed above.

\section{Memorializing the Bamiyan Colossi}

In line with the decision to support community empowerment, Ms. Shukria Neda, representing the civil society in Bāmiyān, was invited to address the 14th Expert Working Group meeting. She gave an impassioned plea for the rebuilding of the two colossal images which she called 'Salsal' and 'Shahmama.' Briefly summarized, the west and largest colossal image (55-m tall) is considered to be Salsal, a legendary warrior from the distant past who was converted to Islam by Hazrat-i Ali, and the 38-m colossal image his wife Shahmama.

This was the first time that the indigenous names for the Colossi were formally entered into the record of a UNESCO Working Group Meeting. In the previous 13 working group meetings the Colossi were identified only as Buddha images. In fact, the Taliban claimed that because they were Buddhist idols, they were an affront to their Islamic faith and must be destroyed. But the residents of the Valley did not identify the Colossi as Buddha images and they resisted their destruction. According 
to the local perspective, the Taliban did not destroy foreign Buddhist idols but rather Bamiyan's history and sacred landscape. As expressed by the Civil Society representative, there was and is a completely different narrative interpretation for the Colossi.

These two perspectives are not in conflict but are instead variant narrative histories of the same colossal images at different phases of their existence. According to the prominent Afghan historian A.A. Khuzad (spelled Khozad in western language publications), there is an evolving narrative history of the Colossi where the preIslamic Buddhist culture that created the colossal Buddhas and the other sacred Buddhist monuments are considered to be part of Afghanistan's glorious ancient history (Greene 2018). I will briefly present the evidence for each of the two major biographical traditions. Thanks to the authoritative survey of the Persian and Arabic sources by Inaba (2019) it is now possible to trace the evolution of the reception of the images from their creation to their destruction. The following is an attempt to summarize a more inclusive history of the Bamiyan Colossi and their reception through the centuries than is currently available in western literature. This in turn should help us to understand the positions of the different stakeholders all of whom, it is hoped, would be acknowledged when the Colossi are memorialized.

\section{Documentary Evidence for the Appearance of the Colossal Sculptures}

The rapid expansion of the monumental Buddhist pilgrimage site began in the second half of the sixth century when the transnational "silk routes" were rerouted over the Hindu Kush mountains, replacing the earlier routes over the Pamir mountains via Gandhara to India (Kuwayama 2002; Klimburg-Salter 2010b; Klimburg-Salter 2019 and bibliography). The most recent C14 analysis suggests dates for the construction of the surviving two colossal images that are also confirmed by comparative art historical analysis. The C14 tests of organic fragments from the Śākyamuni Buddha suggests a date for the so-called "East Buddha" of 544-595 CE (Blänsdorf et al. 2009: 235) (Fig. 2). A judicious interpretation of the evidence would be the late sixth century, although sometimes called the East Buddha, Śākyamuni was originally the center of a Buddha Triad (Fig. 3). The larger "West Buddha," the Dīpamkara Buddha, is believed to have been constructed between 591 and 644 CE (Blänsdorf et al. 2009:235) Combining the latter evidence with the fact that the Great Buddhas were largely completed (although apparently not the paintings in the Buddhas' niches - Fig. 4) by the time of Xuanzang's visit, allows me to suggest, with caution, a date in the first quarter of the seventh century. As a result of both the silk routes commerce and the extensive mineral deposits throughout eastern Afghanistan, Bamiyan experienced a period of great affluence which is reflected in the later Buddhist sites of Afghanistan until the tenth century. The high level of aesthetic, artistic, and technical achievement in the Bamiyan province resulted in 
Fig. 2 Bāmiyān, 38 m niche, Śākyamuni Buddha. (@) Deborah KlimburgSalter / B. Rowland Archive, 1936)

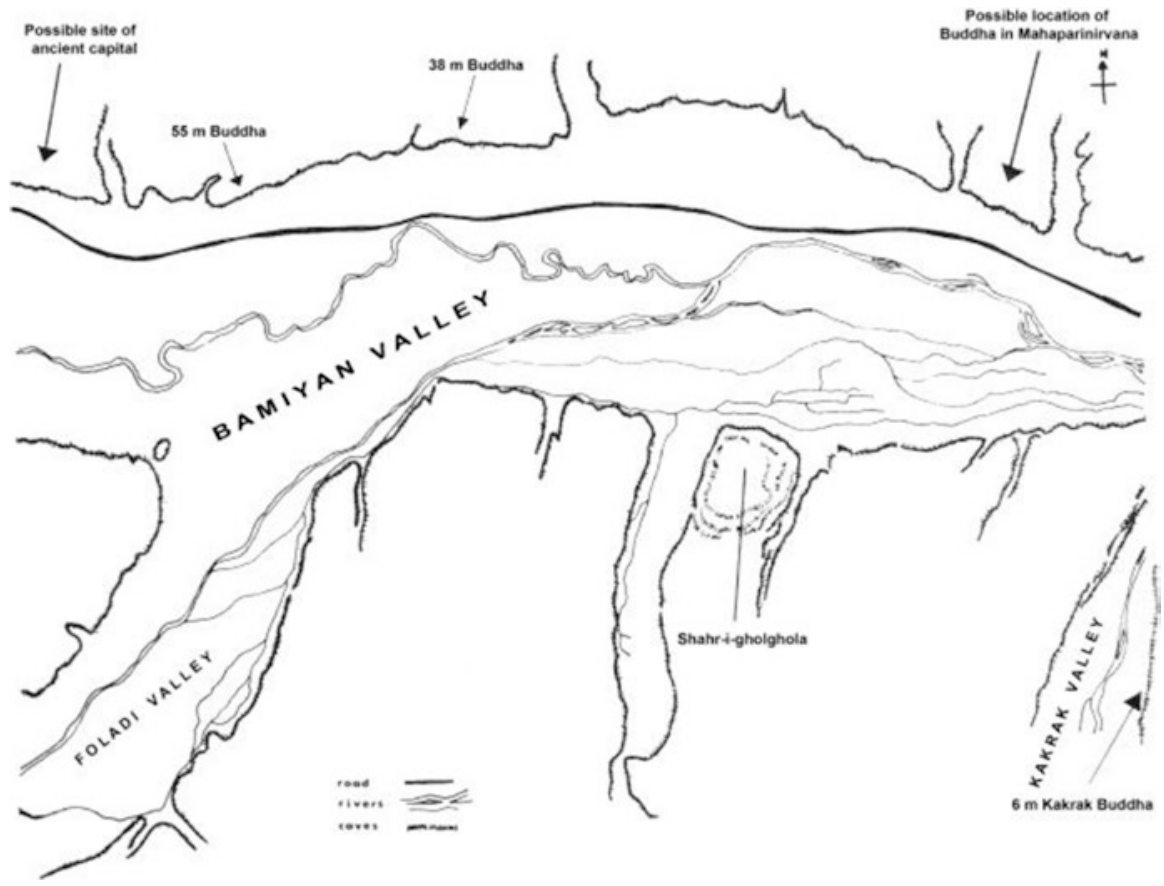

Fig. 3 Bāmiyān valley. (After D. Klimburg-Salter 1989, Map 2) 


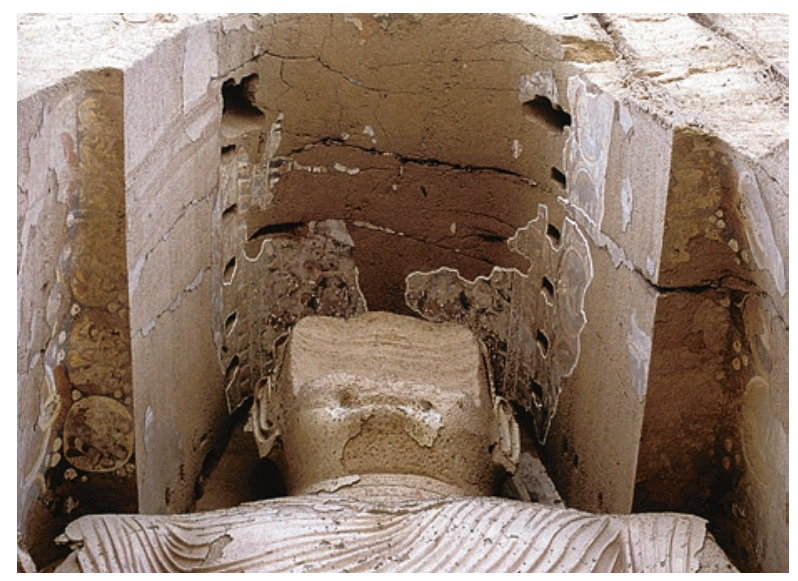

Fig. 4 Bāmiyān. Soffit above the head of 55 m Buddha. (@ D.Klimburg-Salter, WHAV)

the magnificent paintings decorating the monumental niches and rock cut chapels that were marveled at by Islamic visitors (see below) (Taniguchi 2007; Taniguchi and Hidemi 2008). Successive Muslim raids on the Kingdom of Bamiyan took as booty important treasures, which included valuable metal icons. The exact date of the demise of Buddhism in Bamiyan is unknown. ${ }^{1}$ The archaeological indications are that towards the end of the first millennium CE, the Buddhist monastic communities migrated from the Hindu Kush; the people of the Valley gradually adopted the new religion, Islam (Klimburg-Salter 2019; Klimburg-Salter 2008).

We have no reliable visual documentation of the two standing Colossi prior to the photographs taken in the early twentieth century. Hayden 1910 appears to be the oldest. Numerous drawings, of varying documentary value, survive from the nineteenth century. There are only two eyewitness accounts of the Buddhas during the Buddhist period (Klimburg-Salter 1989:12 \& 23)). The most extensive report is from the Chinese monk Xuanzang (Hiuen Tsiang) based on his visit in ca. 630's shortly after the sculptures were completed. This report is our only historical witness for their appearance and methods of construction (Beale 1969r:50-53). I will briefly describe the three colossal Buddhas in the order that Xuanzang performed the ritual circumambulation and meditated upon the spiritual life of the historical Buddha Śākyamuni (Fig. 1). Xuanzang tells us that the three colossal Buddhas (Fig. 3), were in part sculpted out of the rock but also.

with parts of the body separately cast [ in copper alloy], (and then) assembled together (Deeg unpublished translation).

\footnotetext{
${ }^{1}$ Inaba speculates that Islamization occurred during the Ghaznavid period (Inaba 2019). I thank Christine Guth, and Judith Lerner for their thoughtful comments and criticism. And Masanori Nagaoka for his helpful suggestions.
} 
Fig. 5 Bāmiyān, 55 m niche, Dīpamkara Buddha. (C) Deborah KlimburgSalter / B. Rowland Archive, 1936)

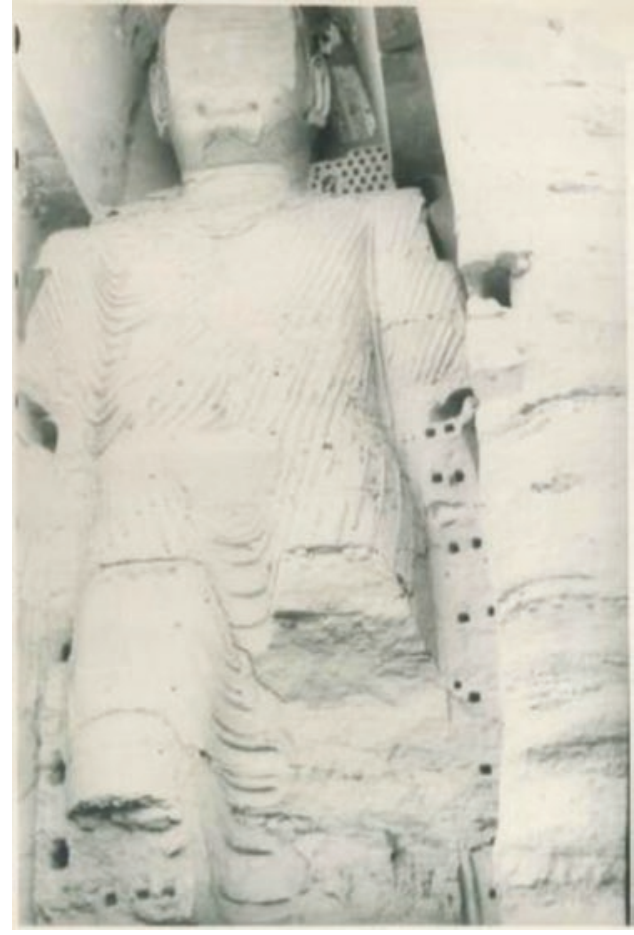

The Buddhist monk began the pilgrimage circuit by worshipping at the great western Buddha - i.e., the 55-m-high colossus, which I propose to identify with Dīpamkara, the Buddha of the Past (Fig. 5) (see Klimburg-Salter 2019 for complete documentation).

swaying with golden color, (and) shining with (its) bejeweled decoration (Deeg unpublished translation).

According to Xuanzang's description, it is possible to infer that at least the Dīpamkara Buddha had a crown and wore jewels. It is very rare for Buddhas to wear jewels. In the rare instance that a Buddha wears jewels then he also wears a crown (Klimburg-Salter 2010a). Sengupta (1989), Tarzi (1977) and Klimburg-Salter (1989) were able to examine the Buddhas with the help of the scaffolding (constructed by the Archaeological Survey of India conservation team) and came independently to the same conclusion. The faces of the Buddhas were actually metal masks to which a crown and earrings were attached, perhaps also a necklace, this is discussed in detail in the next section-

An indication of how the 55-m Buddha might have looked can be seen in Fig. 9 which shows a Nepalese processional image of Dīpamkara wearing a copper alloy mask to which a crown and jewels were attached.

Next Xuanzang identified the Buddha Śăkyamuni (Fig. 2) whose image originally was the center of the colossal Buddha Triad. And, finally, he described the 
third parinirvāṇa Buddha, (Śākyamuni's release from future rebirth). According to Xuanzang, this Buddha, probably at the end of the rock façade (for the detailed interpretation of the narrative program of the great façade Klimburg-Salter 2019; Klimburg-Salter 1989) (Fig. 3). This was where the king convened the Great Assembly at which he donated all his possessions, including himself, to the Buddhist sangha (community) in order to ensure the safety of the kingdom and for the benefit of all living beings (Klimburg-Salter 1989, 2019). The parinirvāna Buddha is never mentioned again. A reasonable hypothesis is that this Buddha image which was lying horizontally is buried under the collapsed part of the cliff still visible at the eastern end of the façade. The Bāmiyān Valley is located in a seismically active zone, and the collapse of the façade could have occurred as the result of two large earthquakes within a 30 year period. A massive earthquake was recorded in June of 819 and a second in 849 (Ambraseys and Bilham 2003). This could explain why none of the literary sources after this date mention the parinirvāna Buddha (Fig. 3). ${ }^{2}$

\section{Methods and Materials: Transformation and Dissolution}

A study of the materials and methods of construction for all three Buddhas has demonstrated that what appeared to western observers as evidence of iconoclasm were actually changes in the fabric of the images resulting from two factors, human intervention, particularly in the tenth century, (the voluntary non-destructive removal of the copper-alloy masks and arm coverings), and the interaction between the material substance and the severe climatic and geologic conditions (KlimburgSalter 2020 includes bibliography; conservation research reports in Petzet 2009).

Therefore, I will only discuss here the two aspects of the changes in the appearance of the Colossi which are particularly important for this discussion. That is the evidence for the metal masks and arm plates and their voluntary removal; and the missing parts of the lower body (left side) of the Dīpamkara Buddha. These are key points in understanding the transformation of the Colossal Buddhas into mythic folk heroes.

Both of the two standing Colossi, and probably also the third lying Buddha, were built upon a core image chiseled out of the conglomerate rock façade. A composite clay body was then applied to the rock core and the subsidiary wooden and rope armature were affixed; final details such as the robes were finished by several layers of gypsum plaster, which was then painted. According to notices in Islamic texts and the archaeological evidence the $55 \mathrm{~m}$. Dīpamkara Buddha's robes were painted red and the Śākyamuni Buddha's robe grey-white.

\footnotetext{
${ }^{2}$ These two severe earthquakes also would have caused some damage to the two standing Buddhas and this could well account for the signs of ancient repair and repainting on the Buddhas' robes (Blänsdorf and Melzl 2009: 211 ff.).
} 
The $55 \mathrm{~m}$. Buddha has been documented in a series of photographs taken over the course of the twentieth century. Because of its enormous scale, the final outer construction consisted of composite clay horizontal slabs with finishing layers of plaster. Each slab was quite heavy. The gaps left when the entire horizontal section pulled away suggested to some observers that the image had been deliberately shot at (Klimburg-Salter 2020 for a complete description of the methods of construction) (Fig. 5). The armature for the Buddhas' forearms were made of thick wooden beams to which metal sheets were attached; indeed, the holes for the thick wooden armature for the forearms are clearly visible (Fig. 5) (for a detailed discussion see Klimburg-Salter 2020). The right hand of the 55-m Buddha was clearly raised as in the sculptures of Dìpamkara from Shotorak (Klimburg-Salter 1995) and Mes Aynak (Klimburg-Salter 2018: Fig. 17).

The monumental masks are the only possible explanation for the identical and unusual cuts on the faces. Such precise and identical modifications to the stone faces could not both have resulted from "mutilation" (as described in Moorcroft and Trebeck). Tarzi's sketches (Fig. 6a, b), and my photograph (Fig. 6c) clearly show that both Buddhas' faces have an identical vertical slit with a shelf and a small trough behind the slit where a metal mask on a wooden armature would have been anchored (Fig. 4). Underneath, and around what would have been their ears, are holes that show that the mask was also anchored next to the ears (Fig. 7). There are holes under the sculptures' ears that might also have anchored earrings that were attached to the crown. Blänsdorf and Melzl (2009: 213) misquote Sengupta and

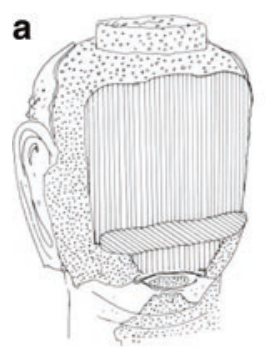

b

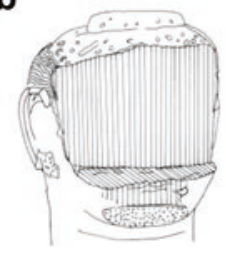

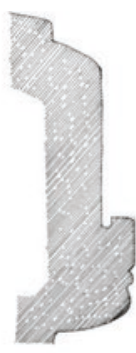

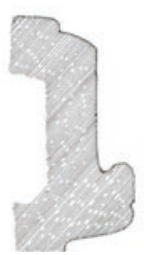

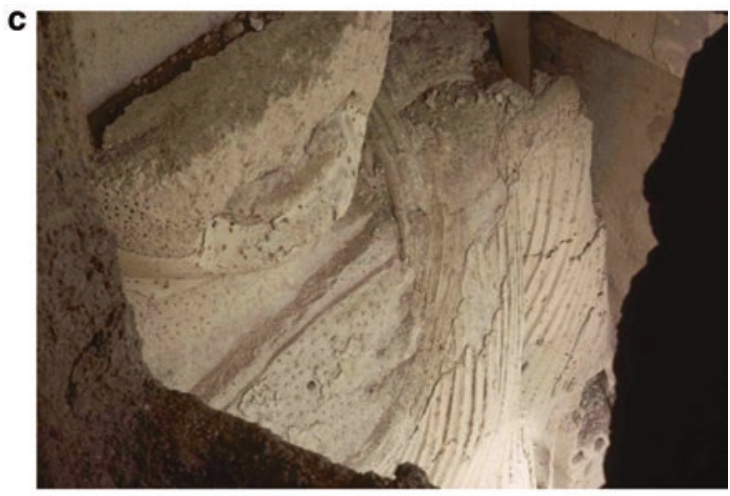

Fig. 6 (a, b) Bāmiyān. Sketch of Buddhas faces (now identified (a) $55 \mathrm{~m}$ Buddha (b) $38 \mathrm{~m}$ Buddha), ledge intended to anchor the masks. (After Z. Tarzi 1977, Fig. 18). (c) Bāmiyān. Chin of $55 \mathrm{~m}$ Buddha. Note charred wood fragments and debris in crevice above ledge meant to anchor the mask. (@ D. Klimburg-Salter, WHAV) 
Fig. 7 Bāmiyān, 38 m niche. Detail ear of Śākyamuni Buddha. (C) Deborah KlimburgSalter / B. Rowland Archive, 1936)

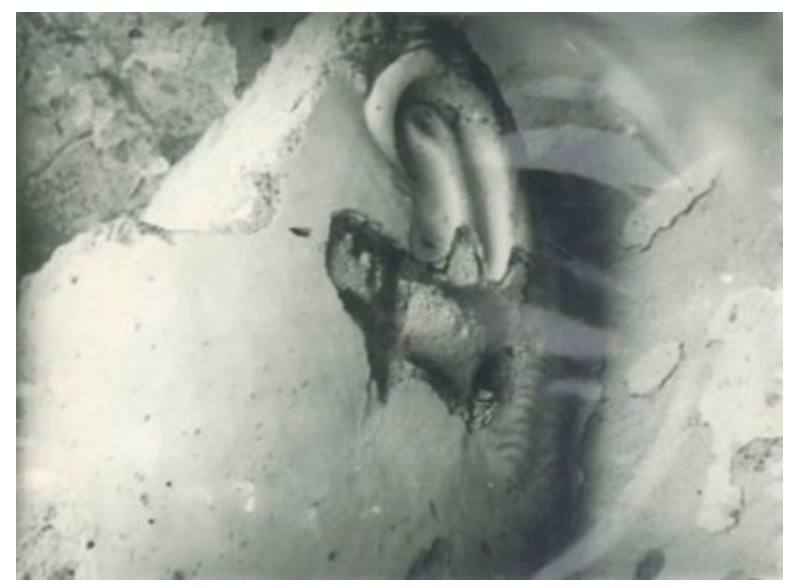

Tarzi thus reversing their conclusions (see also Klimburg-Salter 2020 for further details). ${ }^{3}$

On both sculptures all the incisions have clean edges, the identical vertical cut in the rock above the chin where the face would have been (Fig. 6a, b) as well as the holes around the ears (Fig. 7), show no signs of violence. Thus we see that, the gaps or holes in the sculptures that nineteenth century British travelers interpreted as the result of Muslim mutilation of the face and hands are in fact the remains and indications for the structural supports that originally carried the metal parts described by Xuanzang, and that these metal parts were subsequently voluntarily removed as the monastics retreated from the Bamiyan Valley (Fig. 8).

Further evidence supporting the proposal for the monumental metal masks and arm plates is also the literary evidence for skillful metalworking in the region such as the life-size Buddha described by Xuanzang in Kapiśa (Beale 1969r:54-55). Such monumental metal working is logical given the vast mineral deposits in central Afghanistan, particularly the enormous copper mine at Mes Aynak.

\section{The De-Consecration of the Colossal Buddha}

Only scant indications exist that the Buddha sculptures were significantly changed after the initial period of their creation (Klimburg-Salter 2020). The first major alteration to their appearance occurred when they were taken out of active worship. We do not know exactly when, but we can assume from the C14 evidence for the chronology of the paintings in Bamiyan (active into the ninth century) and the

\footnotetext{
${ }^{3}$ Crowned and bejeweled Buddhas are a distinguishing feature in the wall paintings of the art of the Hindu Kush and adjacent areas Klimburg-Salter 1989, 2019). For instance one surviving example of a crowned Buddha identified as Śākyamuni from the Shahi period is certainly contemporaneous with the art of Bamiyan. (Klimburg-Salter 2010a).
} 
Fig. 8 Bāmiyān, 38 m Buddha. (@ D. KlimburgSalter, WHAV)

Fig. 9 Copper alloy monumental mask, sitting on fabric torso, so that when a man carries the Dīpamkara mask in procession, Dīpaṃkara Buddha towers over everyone and everything else. Bhaktapur. Nepal. (C) A. Graldi, 2012, WHAV)
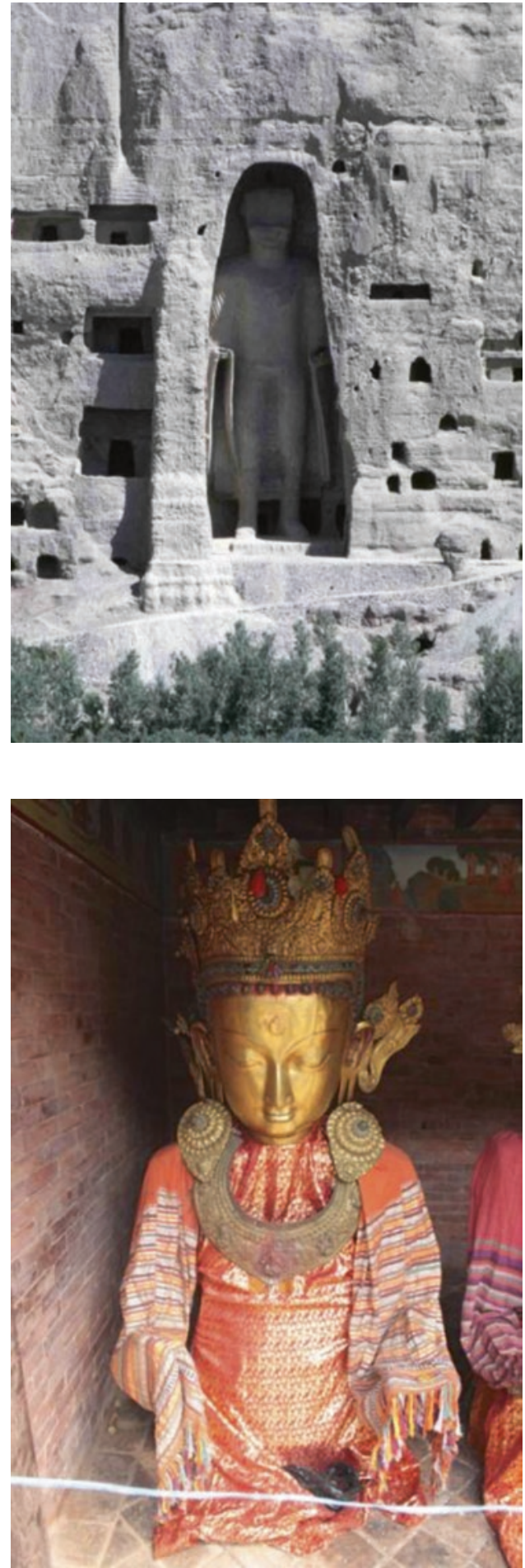
adjacent valleys of Kakrak and Foladi where active work on the wall paintings continued in the tenth century (Nakamura 2006) that the monks who were responsible for the monumental pilgrimage site in Bāmiyān left the Valley at some point in the tenth century. Extrapolating from the $\mathrm{C} 14$ dates for the mural paintings, Buddhist artistic activity continued in Bamiyan until the ninth century, while the latest paintings in the caves in the adjacent valleys of Kakrak and Foladi date into the tenth century (Nakamura 2006: 117-129; Klimburg-Salter 2008).

Archaeological and literary evidence indicate that the conversion of the population to Islam was a gradual process (Paiman and Alram 2010:38; Klimburg-Salter 2008). Religious self-identification was fluid during this period, and for this reason one can only speak of an Islamic historical period in this region from the beginning of the 2nd millennium, that is from 1000 CE (Klimburg-Salter 2008, 2019). One important archaeological indication for the final phase of occupation by the Buddhist community comes from the Buddhist chapels in Kakrak (Fig. 3). The magnificent painted cupola and drum, divided between the Musée Guimet (Paris) and the Kabul National Museum, were preserved apparently because before leaving, probably also ca. tenth century, (Klimburg-Salter 2019:199) the monks covered the paintings with a kind of mud plaster that protected the surface and its brilliant colors until their discovery by French archaeologists in the first half of the twentieth century (Hackin and Carl 1933:39-46). Thus, I tentatively conclude that, in a similar manner, the monks who were associated with the chapels in Bāmiyān had enough time to prepare an orderly retreat. This evidently involved removing the metal parts including the masks of the Buddhas and taking them away. The lavish collection of metal sculptures in the Potala in Lhasa-some of very large size and many coming from the northwest of the subcontinent- testifies to the ability of contemporary Buddhists to transport large, heavy and valuable metal objects over long distances (KlimburgSalter 2010a, b, 2015).

When Buddhism ceased to be practiced in the Valley, and the colossal images were no longer worshiped, the images were de facto de-consecrated by removing their faces, that is the metal masks, and the metal plates covering their arms. Thus, from both a Buddhist and an Islamic point of view they were no longer "living" idols. And indeed, no Islamic source refers to the Colossi as Buddhist idols, they are simply called idols and one author writing about 1270's confesses that "Nothing is known about the character of the shrine nor of the idols". (Inaba 2019:82 and footnote 33). There is also no evidence in the Islamic sources, that the Colossi were the object of iconoclastic attacks prior to the twenty-first century. ${ }^{4}$

The removal of the metal face mask and arm coverings created the strange, even awe-inspiring appearance that characterized the Colossi from the late tenth century until their demise at the beginning of the twenty-first century. In addition, as they were no longer in worship they were no longer from an Islamic perspective, an

\footnotetext{
${ }^{4}$ I thank Minoru Inaba for discussing the sources and their interpretation, see Inaba 2019, as well as discussing the central thesis of this article. He summarized his view in an email August 2019, "As a whole, the basic tone of my paper is that the explosion of the Buddhas in 2001 was the first massive intentional destruction of the monuments in Bamiyan, as far as we see from the sources."
} 
anathema. These two points help in part to explain the rapid evolution from idol (but) to "wonder" ( $A j \bar{a}$ ' $i b)$. Once the Colossi were categorized as 'Aja' $i b$ the statues could be introduced into trans-historical narratives and eventually integrated into the cycle of stories associated with Hazrat-i Ali. Thus at least from the late eighteenth century, Salsal and Shamama had become part of the mythic history of the Islamization of the Bamiyan Region.

This is a critical new perspective that assists us in understanding the most important discrepancy between the Islamic sources, including the Afghan oral traditions, and the western sources.

\section{Entangled Narratives: Islamic Sources}

By the end of the first millennium CE, when the Colossi were no longer "living" idols, the identity of the Colossi as Buddhas faded from the collective memory. A Persian geography ca. 982 identifies the Colossi only by their colors (Minorsky 1970:109), they were called the red (surkh) idol (but) and white/grey (khing) idol (but). ${ }^{5}$

Islamic sources continue to identify the two Colossi by these names but in the late twelfth century one source noted that no one knew who worshipped them or to what cult the idols belonged (Inaba 2019:83 footnote. 33). In the sources dating to the late 12th and early 13 th centuries the Colossi were usually described within their marvelously painted niches. Thus, the total enormous configuration was described as fabulous in appearance (Inaba 2019:79-82). As a result of the assumption of their miraculous origin the Colossi came to be classified as "wonders" (Arabic 'Aja' 'ib) (Inaba 2019:85) demonstrating the "marvelous and uncanny design of God's creation" (Inaba 2019:93 and references in footnote 56). As Inaba explains, once the marvelous monumental painted Bāmiyān Colossi and their niches came to be classified "as a 'wonder' not as an historical fact" (Inaba 2019:92) they were not considered in conflict with Islam. Within this context, fanciful stories developed which have caused considerable confusion regarding the appearance of the Colossi, most particularly the enigmatic problem of the missing faces. Adding to the magic of the Colossi, as also reported almost 1000 years ago, was how their appearance changed according to where one stood, the time of day and the season (Inaba 2019:79). If one stood at the foot of the larger colossal statue, its mate was not visible. Looking up from this position, what one saw first were the brilliant paintings in the heavenly niche enclosing the image (Fig. 4). And then one realized there was no face, but a sheer rock surface. The bizarre shape naturally gave rise to all sorts of fantasies.

\footnotetext{
${ }^{5}$ Indeed traces of red were still observable on the robes of the Dippamkara Buddha in the late twentieth century and examination of the fragments have confirmed that originally the $55 \mathrm{~m}$. West Buddha had red robes and the $38 \mathrm{~m}$. Śākyamuni Buddha had grey-white painted robes (Blänsdorf et al. 2009).
} 
Because of their great size and the significant distance between the two colossi, about $500 \mathrm{~m}$, one could only see the two Buddhas at the same time when one stood on a promontory at the opposite side of the Valley (Fig. 1). Because of the depth of their richly painted niches, which were meant to protect them from the severe climate, their faces were usually hidden in shadow, as one sees here in the 1936 photographs (Figs. 2 and 8). In fact as we see (Figs. 4 and 6a, b) only the bottom part of the face remained. As the sun crossed through the sky the shadows changed and gave rise to various poetic impressions - "These idols weep when the sun goes down and smile when the sun rises." (Inaba 2019:79 footnotes 21 and 22 for references).

During the period under discussion, Bamiyan was one of the capital cities of the Ghorid empire, following its destruction by the Mongols in the early thirteenth century however, the city never regained the prominence it had until that time. Subsequently Bamiyan is mentioned less frequently in the literature.

From the Moghul period the outlines of a distinctive cultural identity appears that included a narrative mythic framework to explain the miraculous images. It is also from this period that Bamiyan and the surrounding area is first identified as a tourist destination. The Moghul emperor Babur (r. 1494-1531) famously passed through Bamiyan several times, although he never mentioned the great Colossi. His brother, Jahāngīr Mīrzā delayed joining Bābur's party because he wanted to visit Bāmiyān for sightseeing "(Inaba p 11 and ftn 55 for citations).

By the seventeenth century, a Moghul text, the Ain-i-Akbari, describes three colossal images: the largest is identified as male, the next in size as female and the smallest of the three sculptures was identified as their child (Inaba 2019). ${ }^{6}$ This is the first indication that the Colossi had begun to be integrated into a localized biography.

\section{Entangled Narratives: Western Literary Sources}

The earliest western language reference to Bamiyan known to me dates from 1758 (Wilford 1758) and contains a linguistic corruption of the names Salsal and Shahmama. The reports of the English travelers who actually visited the Bamiyan Valley begin in the early nineteenth century. They are more or less detailed, but they are essentially consistent in what they report. A careful reading of the nineteenth century descriptions reveals disjointed fragments of the local legends scattered in all their reports. The salient parts of the tradition that survive in a coherent way in the Afghan oral and written sources - are the names Salsal and Shahmama (recorded by the western travelers with slight variations in spelling) whose narrative is part of the cycle of legends reporting the miraculous feats of Hazrat-i Ali. To take only a few

\footnotetext{
${ }^{6}$ It is not clear which of the remaining Buddhas is considered to be the child, it could be either the largest of the three seated Buddhas in the external niches, in the Bamiyan Valley perhaps " $H$ " (Klimburg-Salter 1989) or the very large standing Buddha in the nearby Kakrak Valley.
} 
examples, Alexander Burnes, notes the fact that the "male and female" Colossi were named Salsal and Shahmama respectively (1834:164-188). He also reports "that local traditions "mix up" the histories of the Colossi with [Hazrat-i] Ali, the fourth Caliph (Burnes 1834:182). Thus, Burnes is the first to demonstrate that the local population did not consider the Colossi to be Buddhist idols, however he does notice certain affinities to Buddhist images without coming to a definitive conclusion. Despite the fact that the English sources reported that the Colossi had local names (Moorcroft and Trebeck 1842:388) and that some placed the Colossi in a narrative context, all the English visitors preferred to interpret the Colossi within their respective frames of reference. A predisposition not unique to English travelers, Mohan Lal, a Kashmiri Munshi (Mohan Lal 1846) interpreted the Colossi within the contexts of his Hindu religious tradition. Moorcroft's experience at other pre-Islamic sites indicated to him that the" mutilated" bodies and particularly the incomplete condition of the faces suggested Muslim iconoclasm. ".. both figures have been mutilated. The faces and forearms are broken off and a thigh of the larger [figure] was broken. "(Moorcroft and Trebeck 1842:389). And this logic has continued up to the most recent publications (Flood 2002). ${ }^{7}$ In retrospect, it was in the early nineteenth century that the divergence between Western and Afghan sources began.

To summarize: There were three critical moments in the reception of the Colossi in Islamic literature: From the tenth century when the images were no longer worshiped and following the removal of their metal face masks and metal arm covers, they no longer had the physical appearance of the Buddha - thus they were no longer "living" idols. Then, in the late twelfth century they began to be identified as $\left.A j \bar{a}{ }^{\prime} i b\right)$ "miraculous" creations and thus transcendental figures no longer bound by historical fact (Inaba 2019:87ff.). By the late eighteenth/nineteenth century the extraordinary natural and sculpted formations of Bamiyan were explained within a framing devise of the miraculous deeds of Hazrat-i Ali and the mythic history of the introduction of Islam in the Bamiyan region. These legends have long been an essential part of the repertoire of the bardic singers of Afghanistan (Klimburg 1966:163). ${ }^{8}$ The evidence of these legends in Bamiyan can be traced back at least to the late eighteenth century but they appear to have been transmitted in written form to a wider, mainly Afghan, audience only since the early twentieth century (Khozad).

\section{Entangled Narratives: Salsal and Shahmama}

In the early twentieth century the narratives surrounding the Colossi are radically transformed again. As a result of the French-Afghan archaeological exploration in Bamiyan, the Buddhist origins of the Colossi were re-discovered (MDAFA Vs. II,

\footnotetext{
${ }^{7}$ Occasionally a specific person is suggested as responsible for shooting canon at the idols. I was never able to locate a single primary source to confirm these assertions.

${ }^{8}$ It should be remembered that the most important pilgrimage site in Afghanistan is the supposed tomb of Hazrat-i Ali, the 4th Caliph, which has given the town its name Mazar-I Sharif (noble shrine)
} 
III; Hackin \& Hackin 1934; Green 2018; Godard trans. Khuzad 1315/1936). The DAFA publications expanded the understanding of the cultural-historical context in which the Colossal Buddhas were created. Shortly thereafter (from 1937) the popular oral traditions recounting the Islamic appropriation of the Colossi and other pilgrimage sites were published in Dari and French. The scholarly narrative did not negate the local mythological narrative for the Colossi but integrated these stories into the narrative history of Afghanistan. Ria Hackin and Ahmad Ali Khozad recorded the most widespread legends about the Colossi, which they published in a book of Afghan folktales (Hackin and Khozad 1953). These legends transform the Bamiyan region into a sacred landscape at the center of which stand the Colossal images Salsal \& Shahmama (Hackin and Khozad 1953: 3-21). The recitation begins - "although the whole world knows that the two colossi represent Buddhas the inhabitants of Bamiyan are not of our opinion" (p.20). The most popular legend identifies the largest Buddha as the ancient warrior Salsal and the smaller is his wife Shahmama. At the time that Islam was introduced to Bamiyan Salsal, the most valiant warrior of the ancient kings who defended the territory against the Muslim armies tyrannized the population. The latter then sought help from the Prophet Mohammed. Despite the Prophet's detailed instruction to Hazrat-i Ali he could not subdue Salsal who was protected by magic armor bequeathed to him by the prophet David. Returning to Mecca Ali sought council, following the Prophet Mohammed's instructions, Hazrat-i Ali was able to conquer the great warrior. Having witnessed the wisdom and power of Hazrat-i Ali, Salsal and Shahmama and their followers accepted The True Religion, converted to Islam and from that time onward protected the people of Bamiyan. ${ }^{9}$ Astonishingly, although references to the indigenous identity of the Colossi appear continuously in the English language literature from the 18th century only selective parts of this narrative have been integrated into the western perception of the Colossi and the culture of the Bamiyan Valley. Thus, the self -referential conclusions regarding iconoclastic attitudes reported by the early western sources continue to be transmitted in the western literature. Even the most popular English language guidebook recounts the stories of miracles performed by Hazrat-i Ali in the Bamiyan region - at the Band-i Amir Lakes and Valley of the Dragon - as published by Khozad (Dupree 1971:113-130) but do not mention at all

\footnotetext{
${ }^{9}$ It is not possible to speculate here about the cultural context in which the legends of Salsal and Shahmama first arose, perhaps in the eighteenth century. There is no evidence relating the origin of these legends to any of the ethnic groups that lived in the region. Centlivres gives a good short summary of the troubled history of the Shia Hazara in Bamiyan throughout the last century (Centlivres 2001:99-102). During the civil war, in the late twentieth century, an Hazara political movement emerged, one strand of their discourse was the identification of the Colossi with the Hazara people (Centlivres 2001:102; Husseini 2012). But, Centlivres describes the Buddhist monuments in the late twentieth century, as devoid of religious meaning (in the Islamic world) their only remaining functions as "humble and prosaic" (2001:101). Certainly, the political tensions and goals are of great importance, but it is incomplete to ignore the religious dynamics that continue to flow through the site and the Valley. The Colossi have lost their Buddhist function but the land and the monuments have been appropriated through the local legends and religious practices, including at the pilgrimage places and the Ziyarat,
} 
the related stories about Salsal and Shahmama from the same Hazrat-i Ali legend cycle (Hackin and Khozad: 3-21). Instead the guidebook presents only the Buddhist narrative which is in fact the shortest part of the biography of the Colossi. And it is this history which has served as the basis for some of the proposed solutions for the empty niches.

Confronted with the monumental remains of the pre-Islamic past, it was natural that the people of Bamiyan would take special pride in their Islamic identity and through a slowly expanding mythic history attribute the bounty of the land and the truly extraordinary (indeed one could say miraculous) natural features of the landscape to the intersession of Hazrat-i Ali at the dawn of the Islamic presence in Bamiyan. ${ }^{10}$ Sacred spaces continue to evoke a sense of reverence across millennia independent of cultural definitions. For example, throughout Italy churches are built over Roman, pre-Christian, sacred places, and in Afghanistan Ziyarat (mausolea) are built on or next to pre-Islamic shrines. The fragmentary Colossi without faces and hands had no visual characteristics identifying them as Buddhas, they were not "living" idols, and could thus be reinterpreted within the context of the mythic history of the conversion of Bamiyan to Islam. Through Khozad's important positions and publication activities he influenced several generations of the Afghan educated elite (Green 2018; Khuzad (1334/1955). Khozad's goal was to produce a normative cultural history of Afghanistan in which the Buddhist phase was just one chapter in a long and glorious historical narrative. ${ }^{11}$ Perhaps the most interesting example of this slightly different prism on the history of Afghanistan is Kohzad's translation (Godard trans. Khuzad 1315/1956; Green 2018) of Godard's influential archaeological publication MDAFA II (Godard et al. 1928).

It was in fact the Taliban, at the beginning of the 3rd millennium who brought the Bāmiyān Colossi once again onto the world stage insisting that they were Buddha idols, although it is more than a 1000 years since they were "living" Buddhas and the focus of Buddhist pilgrimage and worship.

\section{The Goals of Heritage Preservation}

Conversations with Shukria Neda revealed that the destruction of Salsal and Shahmama symbolized for the residents of the Bāmiyān Valley not only an attack on their identity but more broadly the trauma of the suffering and destruction during

\footnotetext{
${ }^{10}$ For insistence it is recounted that Hazrat-I Ali created the magnificent 5 lakes called Band-I Amir which then provided 5 water channels to irrigate the Bamiyan Valley.

${ }^{11}$ Unfortunately, there was very little archaeological exploration of the Islamic period, although diverse Islamic monuments dating from the Ghorid period onward, dotted the landscape. Thus also the heterogeneous culture of Bamiyan province remained obscure. See for instance the recently published Judeo-Persian documents believed to have been found in the Bamiyan region (Haim 2019) Thus even experienced anthropologists are unaware of the rich and varied religious life of the Bamiyan Valley and its historical roots.
} 
the civil war, and most particularly during the Taliban regime. Her belief appeared to be that if the colossal sculptures were to be reinstated, then tourism and, hence, prosperity would return to the Valley.

In fact, the loss of tourism is only one of the economic disasters that beset the valley during the long civil war. The broad and fertile Bāmiyān Valley normally provided excellent conditions for agriculture, including pasturage for animal husbandry. But during the Taliban regime, there had also been an extreme drought. This economic disaster was accompanied by massive human rights violations against the Shia Hazara population Thus, there was not only massive material and human loss but also an assault on the distinctive cultural identity of a majority of the residents of the Valley. ${ }^{12}$

\section{Heritage Preservation}

As stated at the beginning of this discussion, my hypothesis is that the best way to identify "holistic strategies for the protection of human rights and promotion of peacebuilding" (p.4). was to understand the changes in the appearance and meaning of the Colossi from their creation to the present time. From the literary and archaeological sources, we learned that both the physical appearance of the Colossi and their cultural contexts have changed over the centuries, and thus the reception, interpretation and importance of the Colossi have changed too. There were three major moments in the narrative biography of the Colossi, their initial creation, ca. late sixth early seventh centuries as Colossal Buddhas: the deliberate removal of the precious metal adornments - the copper alloy face/masks and arm covering ca. tenth century; and from at least the eighteenth century, their evolution into Salsal and Shahmama, mythic heroes in the cycle of miraculous stories associated with Hazrat-i Ali.

"Reconstruction of cultural heritage due to acts of deliberate destruction must be addressed not merely from the point of a material conservation philosophy but within the context of holistic strategies for the protection of human rights and promotion of peacebuilding" (p.4). "It is of central significance [that all stakeholders].... recognize the importance of the role culture can play in the peacebuilding and development process specifically in conflict or post-conflict regions (p.5). (UNESCO Kabul 2016).

In light of this better understanding of the entangled biographies of the Colossi, I suggest that we must rephrase the question posed at the beginning, and ask rather,

\footnotetext{
${ }^{12}$ In fact, there is no reliable census of the population. During the last century there had been significant shifts of the different ethnic groups throughout the province. The Hazarra are considered to be the majority in the Bamiyan Valley, the suggested numbers vary widely. But within the different Valleys of the province are also Tajik, Kizilbash and Pushtu who also at various times impacted the history of the region. Among the latter are also the nomadic and semi-nomadic peoples who possess seasonal grazing rights.
} 
is it possible to create a single physical colossal image in one of the niches? And if so, which narrative biography should be memorialized? The original Buddha narrative that has long disappeared, only to be resurrected by the Taliban, or the legendary Heroes Salsal and Shahmama, who, according to local tradition, had been converted to "The True Faith "at the dawn of the Islamic period in Bāmiyān.

And what criteria could be used for the materiality of this physical presence. There is no documentation for the original Buddha figures and thus according to all international criteria it is impossible to recreate the original Buddhas. There is reliable documentation for the Colossi at the end of the twentieth century, when they were, materially speaking, the sum total of their history. There is adequate documentation both for their appearance and the materials used to rebuild one of those images. But is it feasible to rebuild one of the fragmentary Colossi as they were prior to their violent destruction?

And perhaps even more importantly is a physical presence the appropriate solution?

The colossal Buddha images sheltered in their brilliantly painted niches were seen as symbols of peace by the distant ancestors of the people of the Bāmiyān Valley who laboriously carved the monumental sculptures out of the living rock. Today, the empty niches bear witness to the futility of war and the suffering of the Afghan people, including the residents of Bāmiyān, at the beginning of the third millennium CE. Once again, the great Colossi have been transformed in the imaginations of those who experience them - now, through their absence.

In my, opinion, a far more powerful symbol would be the absence of any specific image. There are those who support the notion of leaving the niches empty as a memorial to the futility of war. This is not a new idea. Both Ground Zero in New York and the Hiroshima Peace Memorial are eloquent expressions of massive loss and destruction. The Hiroshima Peace Memorial is made of several different components, but the image that seems to be the most powerful for many who visit the site is the burned-out shell of a large building.

The evocative power of ruins is well known. The absence of an image allows each visitor to complete the space according to his/her own imagination. Then, through a mixed media strategy of interpretive programs, the evolution of the meaning of the two Colossi through the narrative of their history could be recreated. Didactic mechanisms that would allow the long history of Bamiyan to be told, should be integral to the solution for the great niches and the archaeological zone. The story of the voluntary removal of the copper alloy face masks and arm coverings and thus the de-consecration of the Buddhas resulted in the awe-inspiring appearance of the Colossi. The evolution of the reception of the Colossi within the conceptual framework of a Muslim society from 'Ajā'ib (Arabic) "wonders of God's creation" to principal actors in the legendry history of the conversion of the Bamiyan region to Islam would allow the interests of all the stakeholders -Afghan (both national and regional) and international - to be represented.

At Bāmiyān there should be opportunities for all the cultural voices to be heard. The glorious past of the Bāmiyān Valley — both Buddhist and Muslim, is an inspiring story of how artifacts can take on a plurality of meanings so that, seen 
retrospectively, one can envision the non-violent overlaying of cultures. Thus Bamiyan, can once again be understood as symbol of peace.

\section{Bibliography}

Ambraseys, N., \& Bilham, R. (2003). Seismological Research Letters, 74(2), 107-123.

Beale Hiuen Tsiang. (1969r). Si-yu-ki: Buddhist Records of the Western World, translated by S. Beal, 2 vols. London, 1884.

Blänsdorf, C., et al. (2009). Dating of the Buddha statues - AMS 14C dating of organic materials. In M. Petzet (Ed.), The Giant Buddhas of Bamiyan. Safeguarding the remains (pp. 231-236). Berlin: ICOMOS.

Blänsdorf, C., \& Melzl, E. (2009). Technique of modelling the Buddha statues. In: Petzet (pp. 201-214).

Burnes, A. (1834). Travels into Bokhara. Being an account of a Journey from India to Cabool, Tartary and Persia. Also, narrative of a Voyage on the Indus from the Sea to Lahore (Vol. 3). London: John Murray.

Centlivres, P. (2001). Les Bouddhas d'Afghanistan. Lausanne.

Dupree, N. H. (1971). A historical guide to Afghanistan. Kabul.

Flood, F. B. (2002). Between cult and culture: Bamiyan, Islamic iconoclasm, and the museum. The Art Bulletin, 84(4), 641-659.

Godard, A., Godard, Y., \& Hackin, J. (1928). Les Antiquités Bouddhiques de Bāmiyān (MDAFA II). Paris: Les Éditions G. Van Oest.

Godard, A. (1315/1936). Āsār-i Atīqa-yi Budā-ī-yi Bāmiyān. (Ahmad Alī Khān [Kuhzād], Trans., 2 vols). Kabul.

Green, N. (2018). From Persianate pasts to Aryan antiquity. Transnationalism and transformation in Afghan intellectual history, c. 1880-1940. In: Afghanistan (Vol. 1/1, pp. 26-67). Edinburgh: University of Edinburgh Press.

Hackin, R., \& Kohzad, A. A. (1953). Légendes et coutumes afghanes. Paris: Presses universitaires de France.

Hackin, J., \& Hackin, R. F. (1934). Le site archéologique de Bāmiyān. Guide du visiteur. Paris.

Hackin, J., \& Carl, J. (1933). Nouvelles Recherches Archéologiques à Bāmiyān 1930 (MDAFA III). Paris: Les Éditions G. Van Oest.

Hayden, H. H. (1910). Notes on some monuments in Afghanistan. In: Memoires of the Asiatic Society of Bengal (Vol. 2).

Haim, O. (2019). What is the "afghan Genizah"? A short guide to the collection of the afghan manuscripts in the National Library of Israel, with the edition of two documents. In: Afghanistan (Vol. 2/1, pp. 70-90). Edinburgh: University of Edinburgh Press.

Husseini, S. R. (2012). Destruction of Bamiyan Buddha: Taliban Iconoclasm and Hazara Response. In K. Wariko (Ed.), Himalayan and Central Asian Studies (Vol. 16 No. 2 (April-June 2012) (pp. 15-50). New Delhi.

Inaba, M. (2019). The narratives on the Bamiyan Buddhist remains in the Islamic period. In B. Auer \& I. Strauch (Eds.), Encountering Buddhism and Islam in Premodern Central and South Asia (pp. 75-96). Berlin

Klimburg, M. (1966). Afghanistan: das Land im historischen Spannungsfeld Mittelasiens. Vienna and Munich.

Klimburg-Salter, D. E. (1989). The kingdom of Bāmiyān: Buddhist art and culture of the Hindu Kush. Naples: Istituto Universitario Orientale, Dipartimento di Studi Asiatici.

Klimburg-Salter, D. E. (1995). Buddha in Indien. Milan: Skira.

Klimburg-Salter, D. E. (2008). Buddhist painting in the Hindu Kush c. VIIth to Xth centuries: Reflections of the co-existence of pre-Islamic and Islamic artistic cultures during the early cen- 
turies of the Islamic era. In É. de la Vaissière (Ed.), Islamisation de l'Asie centrale. Processus locaux d'acculturation du VIIe au XIe siècle (pp. 131-159). Cahiers de Studia Iranica, 39. Paris.

Klimburg-Salter, D. E. (2010a). A case study in cultural mobility: The crowned Buddha of the Kabul Shah. In M. Alram, D. Klimburg-Salter, M. Inaba, \& M. Pfisterer (Eds.), Coins, art and chronology II. The first millenium CE in the Indo-Iranian Borderlands (pp. 389-406). Vienna.

Klimburg-Salter, D. E. (2010b). Corridors of communication across Afghanistan. In: A. Marigo (Ed.), Paysage naturel et culturel du centre de l'Afghanistan: Hindou-Kouch, Lacs de Band-e Amir, Vallée de Bamiyan Afghanistan (pp. 173-192). Centre d'Etudes et de Recherches Documentaires sur l'Afghanistan. Paris.

Klimburg-Salter, D. E. (2015). Along the pilgrimage routes between Uḍḍiyāna and Tibet: The Gilgit mss. Covers and the Tibetan decorated book cover. In E. Forte, L. Junyan, D. KlimburgSalter, Z. Yuan, \& H. Tauscher (Eds.), Tibet in dialogue with its Neighbors. History, culture and art of central and western Tibet, 8th to 15th century (Arbeitskreis für Tibetische und Buddhistische Studien China Tibetology Research Center) (pp. 392-406). Vienna-Beijing.

Klimburg-Salter, D. E. (2018). Contextualizing Mes Aynak. In: Afghanistan (Vol. 1/2, pp. 213-238). Edinburgh: University of Edinburgh Press.

Klimburg-Salter. (2019). Buddhist Pilgrimage to India: Bāmiyān, Kapisa-Kabul, Mes Aynak. In J. A. Lerner \& A. L. Juliano (Eds.), New research on Central Asian, Buddhist and far eastern art and archaeology (Inner and central Asian art and archaeology 2) (pp. 185-224). Turnhout: Brepols.

Klimburg-Salter. (2020). The materiality of the Bāmiyān colossi, across three millennia. In V. Eltschinger, V. F. A. Tournier, \& M. Sernesi (Eds.), Festschrift: Cristina Scherrer-Schaub. "Series Minor" of the Università degli Studi di Napoli "L'Orientale“. Napels (pp. 1-44). (Khozad is used for the publications in western language/Kuhzad in Persian).

Kuhzad, A. A. (1334 [1955]). Rāhnamāa-ye Bāmiyān [in Persian]. Anjuman-i Tārīkh-i Afghānistān, Kabul.

Kuwayama, S. (2002). Across the Hindukush of the first millennium. A collection of the papers. Kyoto: Institute for Research in Humanities, Kyoto University. Kyoto.

Lal, M. (1846). Travels in the Panjab, Afghanistan, Turkistan, to balk, Bokhara, and Herat; and a visit to Great Britain and Germany. London.

Minorsky, V. (1970, Second Edition). Hudūd al-'Ālam = 'The regions of the world: a Persian geography, 372 A.H.-982 A.D. trans. by V. Minorsky with the preface by V. V. Barthold. E.J.W. Gibb memorial' series (Vol. 11). London.

Nakamura, T. (2006). Radiocarbon dating of straw fragments and wooden joints related with Buddhist mural paintings at Bāmiyān site, Afghanistan. In Radiocarbon dating of the Bamiyan mural paintings (pp. 117-129). Tokyo: Akashi Shoten.

Paiman, Z., \& Alram, M. (2010). Tepe Narenj: A royal monastery on the high ground of Kabul. Journal of Inner Asian Art and Archeology, 5, 33-58.

Petzet, M. (Ed.). (2009). The Giant Buddhas of Bamiyan. Safeguarding the remains. Berlin: ICOMOS.

Sengupta, R. (1989). Restoration of the Bāmiyān Buddhas. In: Klimburg-Salter, D. The kingdom of Bāmiyān: Buddhist art and culture of the Hindu Kush. Istituto Universitario Orientale, Dipartimento di Studi Asiatici. (pp. 202-205). Naples.

Taniguchi, Y. (2007). Issues of conservation for the Bamiyan Buddhist mural paintings. In K. Yamauchi, Y. Taniguchi, \& T. Uno (Eds.), Mural paintings of the silk road. Cultural exchanges between east and west: Proceedings of the 29th annual international symposium on the conservation and restoration of cultural property (pp. 144-151). Archetype Publications, in association with the Japan Center for International Cooperation in Conservation, National Research Institute for Cultural Properties. Tokyo.

Taniguchi, Y., \& Hidemi, O. (2008). The painting techniques, materials and conservation of Bāmiyān Buddhist mural paintings in Afghanistan. In Mural paintings, mosaics and rock art (Vol. 1, pp. 397-404). ICOM Committee for Conservation, triennial meeting preprints. New Delhi 22-26 September 2008. 
Tarzi, Z. (1977). L'architecture et le décor rupestre des grottes de Bamiyan. (2 vols). Paris.

UNESCO Kabul. (2016). Draft concept note. The future of the Bamiyan Buddha statues: Technical considerations \& potential effects on authenticity and outstanding universal value.

UNESCO. (2017a). The future of Bamiyan: An open symposium for the public on 30. September, 2017 Concept Note and Program.

UNESCO. (2017b, October). Recommendations of the 14th expert working group meeting for the safeguarding of the cultural landscape and archaeological remains of the Bamiyan Valley World Heritage Property, Afghanistan (pp. 1-2). Tokyo.

Wilford, F. (1758). On Mount Caucasus. In Asiatick researches (Vol. VL), pp. 462-469).

The opinions expressed in this chapter are those of the author(s) and do not necessarily reflect the views of the UNESCO, its Board of Directors, or the countries they represent.

Open Access This chapter is licensed under the terms of the Creative Commons AttributionShareAlike 3.0 IGO License (https://creativecommons.org/licenses/by-sa/3.0/igo/), which permits use, sharing, adaptation, distribution, and reproduction in any medium or format, as long as you give appropriate credit to UNESCO, provide a link to the Creative Commons licence and indicate if changes were made. If you remix, transform, or build upon this chapter or a part thereof, you must distribute your contributions under the same licence as the original. This publication is also available at the UNESCO Open Access Repository: https://unesdoc.unesco.org/

The designations employed and the presentation of material throughout this publication do not imply the expression of any opinion whatsoever on the part of UNESCO concerning the legal status of any country, territory, city or area or of its authorities, or the delimitation of its frontiers or boundaries.

The authors are responsible for the choice and the presentation of the facts contained in this chapter and for the opinions expressed therein, which are not necessarily those of UNESCO and do not commit the Organization. 